\title{
The Role of Learning Approaches as Mediator between Peer Social Support and Self-Regulated Learning among Engineering Undergraduates
}

\author{
Hafzan A. ${ }^{1}$, Aida Nasirah A. ${ }^{1}$, Norida A. ${ }^{1}$ \& Kalthom H. ${ }^{1}$ \\ ${ }^{1}$ Centre of Languages and Human Development, Universiti Teknikal Malaysia Melaka, Hang Tuah Jaya, Durian \\ Tunggal, Melaka, Malaysia \\ Correspondence: Aida Nasirah Abdullah, Centre of Languages and Human Development, Universiti Teknikal \\ Malaysia Melaka, Hang Tuah Jaya, 76100, Durian Tunggal, Melaka, Malaysia. Tel: 606-331-6931. E-mail: \\ aidanasirah@utem.com
}

Received: January 16, 2015

Accepted: January 28, 2015 Online Published: June 5, 2015

doi:10.5539/ass.v11n17p67

URL: http://dx.doi.org/10.5539/ass.v11n17p67

\begin{abstract}
This study examines the relationship between peer perceived social support, learning approaches and dimensions in self-regulated learning. This study employed a quantitative method through a survey using questionnaires which were distributed to a total of 93 engineering undergraduates from the Universiti Teknikal Malaysia Melaka. The Revised Study Process Questionnaire, LASSI and Multidimensional Perceived Social Support were used to measure students' beliefs about self-regulatory processes, knowledge, learning approaches, and perceived social support from peers. Statistical test for mediation was conducted using a series of regression analyses. Results indicate that out of nine dimensions of self-regulated learning, only three dimensions i.e. information processing $(\mathrm{r}=.22, \mathrm{p}<.05)$, motivation $(\mathrm{r}=.37, \mathrm{p}<.01)$, and self-testing $(\mathrm{r}=.32, \mathrm{p}<.01)$ that were found to be significantly associated with only deep learning approach dimension. Peer perceived social support was found to be associated with students' information processing $(r=.31, p<.01)$ and motivation $(r=.26, p<.01)$. It shows that peers also have significant role in the development of students' ability in processing the information and promote students' needs of achievement. Based on the findings, the following theoretical and practical applications are suggested in order to be applied specifically among engineering undergraduates.
\end{abstract}

Keywords: self-regulated learning, learning approaches, perceived social support

\section{Introduction}

The rapid development of the higher learning in Malaysia brings new challenges and opportunities among students and graduates. The changing technological conditions of human life require individuals to solve a wide range of problems especially for the country well-being. To fulfill these challenging tasks, undergraduates as future leaders must acquire better learning skills to reach their goals in academic achievements. These new challenges make the higher learning and its assets more competitive and dynamic. Higher learning is gaining public attention in terms of the efforts towards appreciation of the knowledge culture and the enhancement of graduates' quality (Zainal, 2009). The academic quality among students in higher education also relates to the Ministry of Higher Education's (MOHE) mission that is to develop a higher education environment that encourages the growth of premier knowledge centers and individuals who are competent, innovative with high moral values in order to meet national and international needs.

The equality of quantity and quality of graduates has always been questioned by educators and academicians. The quality and performance of Malaysian students have been very topical in many discussions at various levels. The deficiencies are not so much on engineering and technical skills, but on the soft skills, namely: psychology knowledge of human interaction, leadership and management skills which fall under humanities and the social sciences domains. Engineers that Malaysian universities produced are required to have good communication skills and other soft skills. Apart from that, students also need to have knowledge in time management, reading skills and motivation in order to be successful. This is supported by Pintrich and Schunk (2002) who argued that in order to achieve better academic performance, engineering students need to be self-regulated and motivated in 
learning and education purpose and also for their future career. In order to achieve this target, self-regulation and motivation would be essential to university students' academic performance.

\subsection{Self-Regulated Learning}

Self-regulated learning is defined as metacognition activities, strategic action (planning and monitoring) and motivation to learn (Buttler \& Winne, 1995; Winne \& Perry, 2000; Perry, Phillips, \& Hutchison, 2006; Zimmerman, 1990). In particular, self-regulated learners are aware of their academic strength by using their own motivational cognition such as concentration, attitude, and information processing. In relation to that, engineering undergraduates whose typically work on lab projects require motivational cognition involving all discussed above dimensions in the self-regulatory.

\subsection{Learning Approaches}

Biggs's (1978) learning approaches model defined three learning styles, which are surface, deep and achieving approaches. Many scholars have discussed the significance of learning approaches towards self- regulated learning. Students are assumed to actively construct their own meanings, goals and strategies from the information available in the class as well as information in their own minds (Pintrich, 2000). For example, deep approaches to learning are considered to correlate with academic attainment, acquisition of process skills and satisfaction with the Malaysian course (Goh, 2005). His result indicates that students who adopt deep approaches to learning had higher academic success than students who adopted surface approaches to learning. Meanwhile Goh (2005), has shown evidence that deep approaches to learning had significant relation with students' academic attainment, acquisition of process skills and satisfaction with their course.

\subsection{Peer Social Support}

Social support is one of the coping resources and has been reported as severity of psychological and physical symptoms and acts as a buffer between stressful lives (Zimet, 1988; Wilcox, 1981). Literature supports peer perceived social support as related to better psychological and physical function. Rubel (2008) has investigated the relationship between students' social supports from their parents, teachers, and classmates and their self-efficacy and use of self-regulated learning strategies. The results clearly demonstrate the need to further explicate middle school students' needs in terms of the supports that they receive in order to attain maximum academic success. Peer group is considered as one part of support group for students in universities or colleges. Adolescence is a transitional period for social support because of their move away from parents as their primary source of support and turn to peer relationships (Slavin-Williams \& Berdnt, 1990). In the process of studying and learning, peers are considered as helper to students to increase the achievement level in academic achievement (Carter, 2000).

\subsection{Objectives}

This study examines two major objectives concerning the relationship between peer perceived social support, learning approaches and dimensions in self-regulated learning. Specifically, the study focuses on the following objectives:

1) To determine the relationship between:

- Peer Perceived social support with learning approaches

- Learning approaches with self-regulated learning

2) To determine if learning approaches mediate the relationship between peer perceived social support and selfregulated learning.

\section{Method}

\subsection{Sampling and Data Collection}

The participants consisted of 93 engineering undergraduates from Universiti Teknikal Malaysia Melaka. Participants consisted of $63(67.4 \%)$ male and $30(32.3 \%)$ female students. A set of questionnaires were collected from second semester undergraduates' degree programme of engineering studies in Universiti Teknikal Malaysia Melaka. The other personal characteristics are defined in Table 1 below. The personal characteristics of the respondents scoped in the current study were sex, faculty, semester of study, academic background, CGPA, and hours of study per day. As shown in Table 1, a majority of the respondents was male students $(67.7 \%)$ and from Electrical Engineering Faculty (FKE) (67.4\%). Further, for 64.1 percent of the respondents are in the fourth semester and most of them (78.5\%) have matriculation certificate. In terms of academic achievement, more than half $(54.4 \%)$ of the respondents have CGPA ranging between 2.75 to 3.5 with a mean of $3(\mathrm{SD}=.4)$. It shows 
that on average, the respondents have good CGPA. In addition, most of the respondents (83.5\%) reported having study hours less than 4 hours per day $(\mathrm{M}=3$ and $\mathrm{SD}=2.4)$.

Table 1. Personal profiles of respondents $(\mathrm{N}=93)$

\begin{tabular}{|c|c|c|}
\hline Variable & $\mathbf{N}$ & $\%$ \\
\hline \multicolumn{3}{|l|}{ Sex } \\
\hline Male & 63 & 67.7 \\
\hline Female & 30 & 32.3 \\
\hline \multicolumn{3}{|l|}{ Faculty } \\
\hline FKE & 60 & 67.4 \\
\hline FKP & 29 & 32.6 \\
\hline \multicolumn{3}{|l|}{ Semester of Study } \\
\hline Second & 6 & 6.5 \\
\hline Third & 1 & 1.1 \\
\hline Fourth & 59 & 64.1 \\
\hline Eight & 26 & 28.3 \\
\hline \multicolumn{3}{|l|}{ Academic Background } \\
\hline STPM & 8 & 8.6 \\
\hline Diploma & 12 & 12.9 \\
\hline Matriculation Certificate & 73 & 78.5 \\
\hline \multicolumn{3}{|l|}{ CGPA Result } \\
\hline$<2.75$ & 30 & 33.3 \\
\hline $2.75-3.5$ & 49 & 54.4 \\
\hline$>3.5$ & 11 & 12.2 \\
\hline Mean & 3 & \\
\hline Standard Deviation & .4 & \\
\hline Min & 2.4 & \\
\hline $\operatorname{Max}$ & 3.9 & \\
\hline Hours of Study per Day & 76 & 83.5 \\
\hline$<4$ & 10 & 11 \\
\hline $4-8$ & 5 & 5.5 \\
\hline$>8$ & 3 & \\
\hline Mean & 2.4 & \\
\hline Standard Deviation & 0 & \\
\hline Min & 12 & \\
\hline $\operatorname{Max}$ & & \\
\hline
\end{tabular}

\subsection{Measurement of the Variables}

All participants in the study have been given a set of test that contains demographic information form, the Learning and Study Strategies Inventory (LASSI), the Multidimensional Scale of Perceived Social Support (MSPSS), and the Study Process Questionnaire (R-SPQ-2F). The original version of the Learning and Study Strategies Inventory (LASSI) by Weinstein (2002) contains 80 items with 10 dimensions (anxiety, attitude, information processing, motivation, self-testing, selecting main idea, study aids, time management and test strategies). Students were asked to give their opinion on each item using a 5-point Likert Scale ranging from (1) 'not at all typical of me' to (5) 'Very much typical of me'. The MPSSS by Zimet (1988) consisted of 12 items with three dimensions of perceived social support (ie, family, peers and significant others). However, only peer support dimension (5 items) was used in the study. Each item was rated on a 7-point Likert type scale ranging from 'Strongly Disagree' (1) to 'Very Strongly agree' (5). Meanwhile, the Study Process Questionnaire (R-SPQ-2F) which was originally developed by Biggs (2001) consists of 20 items with 2 main dimension (Deep 
approach and surface approach). Each item was rated on a 5- point Likert type scale ranging from 'This is never or only rarely true of me' (1) to 'This item is always or almost always true of me' (5).

\subsection{Statistical Analysis}

Pearson Correlation was used to determine the relationship between Perceived social support with learning approaches and Learning approaches with self-regulated learning. Moreover, Multiple regressions analysis was used to examine whether learning approaches could be considered as mediating the relationship between perceived social support and self-regulated learning. A mediation model was tested with learning approaches as the mediator explaining the relationship between perceived social support and self-regulated learning. Statistical test for mediation was conducted using a series of regression analyses. Specifically, four regression equations were computed to test the mediating relationship. First, regressing the dependent variable on the independent variable; second, regressing the mediator variable on the independent variable; third, regressing the dependent variable on the mediator variable and finally, regressing the dependent variable on both the independent and mediator variables in which the mediation is said to occur if the impact of the independent variable on the dependent variable is significantly reduced or to be insignificant after controlling the mediator (Baron \& Kenny, 1986). In addition, the Sobel test was used to assess the statistical significance of the mediation effect (Preacher \& Leonardelli, 2001).

\section{Results}

\subsection{Relationships between Perceived Social Support and Learning Approaches}

Table 2 shows the relationships between Perceived Social Support and Learning Approaches. There were significant relationships between peer perceived social support $(\mathrm{r}=.31, \mathrm{p}<.01)$ with deep learning approach. The positive correlation coefficient indicates that there is an increase in the scores for peer perceived social support followed by an increase in the deep learning approach scores. It implies that students who receive social support from their families and peers are more likely to have deep learning approach. Meanwhile, there were no significant relationships between peer perceived social support with surface learning approach.

Table 2. Relationships between perceived social support and learning approaches

\begin{tabular}{lll}
\hline Perceived & \multicolumn{2}{l}{ Learning Approaches r(p) } \\
\cline { 2 - 3 } Social Support & Deep Approach & Surface Approach \\
\hline Peer & $.31^{* *}(.00)$ & $\mathrm{ns}$ \\
& & \\
\hline
\end{tabular}

${ }^{*} \mathrm{p}<.05, * * \mathrm{p}<.01$.

\subsection{Relationships between Learning Approaches and Self-Regulated Learning}

Pearson correlation analysis revealed that there were significant relationships between learning approaches and dimensions of self-regulated learning (see Table 3). Specifically, out of nine dimensions of self-regulated learning, only three dimensions i.e. information processing $(\mathrm{r}=.22, \mathrm{p}<.05)$, motivation $(\mathrm{r}=.37, \mathrm{p}<.01)$, and self-testing $(\mathrm{r}=.32, \mathrm{p}<.01)$ that were found to be significantly associated with deep learning approach. Result of the study shows that students who have deep learning approach tend to use elaboration, creativity, and organization strategies in learning the material. Result also shows that high achievement oriented students have responsibility for daily tasks, and test their own level of understanding of material.

Furthermore, surface learning approach was associated positively with all dimensions of self-regulated learning which are anxiety $(\mathrm{r}=.53, \mathrm{p}<.01)$, attitude $(\mathrm{r}=.30, \mathrm{p}<.01)$, concentration $(\mathrm{r}=.27, \mathrm{p}<.01)$, information processing $(\mathrm{r}=.41, \mathrm{p}<.01)$, motivation $(\mathrm{r}=.43, \mathrm{p}<.01)$, self-testing $(\mathrm{r}=.28, \mathrm{p}<.01)$, selecting main ideas $(\mathrm{r}=.37, \mathrm{p}<.01)$, study aids $(\mathrm{r}=.21, \mathrm{p}<.05)$, and test strategies $(\mathrm{r}=.26, \mathrm{p}<.01)$. It implies that students who have surface learning approach tend to feel panicky or globalize the effects of an exam but in the same time they have high level of goal setting, and concentration. They have the ability to learn by the use of elaboration and creativity, have motivation to perform specific tasks related to achieving in academic success. They also display ability to identify important study materials and use the resources to help them learn the information. 
Table 3. Relationships between learning approaches and self-regulated learning

\begin{tabular}{|c|c|c|c|c|c|c|c|c|c|}
\hline \multirow{2}{*}{$\begin{array}{c}\text { Learning } \\
\text { Approaches }\end{array}$} & \multicolumn{9}{|c|}{ Self-regulated Learning } \\
\hline & Anxiety & Attitude & Concentration & $\begin{array}{c}\text { Info } \\
\text { Processing }\end{array}$ & Motivation & Self-Testing & $\begin{array}{l}\text { Selecting } \\
\text { Main Idea }\end{array}$ & $\begin{array}{l}\text { Study } \\
\text { Aids }\end{array}$ & $\begin{array}{c}\text { Test } \\
\text { Strategies }\end{array}$ \\
\hline $\begin{array}{c}\text { Deep } \\
\text { Approach }\end{array}$ & $\mathrm{ns}$ & $\mathrm{ns}$ & $\mathrm{ns}$ & $\begin{array}{l}.22 * \\
(.04)\end{array}$ & $\begin{array}{l}.37 * * \\
(.00)\end{array}$ & $\begin{array}{l}.32 * * \\
(.00)\end{array}$ & ns & ns & ns \\
\hline Surface & $.53 * *$ & $.30 * *$ & $.27 *$ & $.41 * *$ & $.43^{* *}$ & $.28 * *$ & $.37 * *$ & $.21 *$ & $.26^{*}$ \\
\hline Approach & $(.00)$ & $(.00)$ & $(.01)$ & $(.00)$ & $(.00)$ & $(.00)$ & $(.00)$ & $(.05)$ & $(.01)$ \\
\hline
\end{tabular}

\subsection{Relationships between Perceived Social Support and Self-Regulated Learning}

As shown in Table 4, results of the study found that peer perceived social support were related to some dimensions of self-regulated learning. Peer perceived social support was found to be associated with students' information processing $(\mathrm{r}=.31, \mathrm{p}<.01)$ and motivation $(\mathrm{r}=.26, \mathrm{p}<.01)$. It shows that peers also have significant role on the development of students' ability in processing information and promote students' need of achievement.

Table 4. Relationships between peer perceived support and dimension in self-regulated learning

\begin{tabular}{|c|c|c|c|c|c|c|c|c|c|}
\hline \multirow{2}{*}{$\begin{array}{c}\text { Perceived } \\
\text { Support }\end{array}$} & \multicolumn{9}{|c|}{ Self-regulated Learning } \\
\hline & Anxiety & Attitude & Concentration & $\begin{array}{c}\text { Info } \\
\text { Processing } \\
\end{array}$ & Motivation & Self-Testing & $\begin{array}{l}\text { Selecting } \\
\text { Main Idea }\end{array}$ & $\begin{array}{r}\text { Study } \\
\text { Aids } \\
\end{array}$ & $\begin{array}{c}\text { Test } \\
\text { Strategies }\end{array}$ \\
\hline Peer & ns & ns & ns & $\begin{array}{l}.31 * * \\
(.00)\end{array}$ & $\begin{array}{l}.26^{*} \\
(.01)\end{array}$ & ns & ns & ns & ns \\
\hline
\end{tabular}

$* \mathrm{p}<.05, * * \mathrm{p}<.01$

\subsection{Relationship between Perceived Social Support and Students' Self-Regulated Learning Mediated by Deep Learning Approach}

According to Baron and Kenny (1986), three assumptions must hold to establish mediation: (a) there is a significant relationship between the independent variable and the mediator, (b) there is a significant relationship between the mediator and the dependent variable, and (c) there is a significant relationship between the independent variable and dependent variable. Applying the three assumptions for establishing mediation, the mediating relationship in the current study could be tested into a model which is the relationship between peer perceived social support and self-regulated learning (i.e. information processing and motivation) mediated by deep learning approach.

3.5 Relationships between Peer Perceived Social Support and Students' Information Processing Mediated by Deep Learning Approach

Based on information in Table 5, deep learning approach did not predict students' motivation when peer perceived social support was also entered into the regression. It shows that the impact of peer perceived social support on students' ability to process the information was not mediated by learning approach. In other words, the peer perceived social support has direct contribution in enhancing students' ability in processing information. 
Table 5. Relationships between peer perceived social support and students' information processing mediated by deep learning approach

\begin{tabular}{|c|c|c|c|c|c|c|c|}
\hline Step & DV & IV & B & SE & $\beta$ & $\mathbf{t}$ & $\mathbf{p}$ \\
\hline \multirow[t]{2}{*}{1} & Info Processing & Peer Perceived Social Support & .19 & .06 & $.31^{* *}$ & 3.03 & .00 \\
\hline & Deep Approach & Peer Perceived Social Support & & & & & \\
\hline \multirow[t]{2}{*}{2} & & & .34 & .11 & $.31^{* *}$ & 3.00 & .00 \\
\hline & Info Processing & Deep Approach & & & & & \\
\hline 3 & & & .12 & .06 & $.22 *$ & 2.08 & .04 \\
\hline \multirow[t]{2}{*}{4} & Info Processing & Peer Perceived Social Support & .16 & .07 & $.26^{*}$ & 2.37 & .02 \\
\hline & & Deep Approach & .07 & .06 & .13 & 1.16 & .25 \\
\hline
\end{tabular}

\subsection{Relationships between Peer Perceived Social Support and Students' Motivation Mediated by Deep Learning Approach}

Results from a series of regression analyses (see Table 6) found that the relationship between peer perceived social support and students' motivation is mediated by deep learning approach. As shown in the fourth regression equations, a full mediation hold in the present study shows the relationship between peer perceived social support and students' motivation dropped to be non-significance when deep learning approach was controlled. A perfect mediation by deep learning approach implied that social support from peer affect students' motivation primarily because of their use of deep approach in learning process.

Table 6. Relationships between peer perceived social support and students' motivation mediated by deep learning approach

\begin{tabular}{|c|c|c|c|c|c|c|c|}
\hline Step & DV & IV & B & SE & $\boldsymbol{\beta}$ & $\mathbf{t}$ & $\mathbf{p}$ \\
\hline \multirow[t]{2}{*}{1} & Motivation & Peer Perceived Social Support & .20 & .08 & $.26^{*}$ & 2.60 & .01 \\
\hline & & Peer Perceived Social Support & & & & & \\
\hline 2 & Deep Approach & Deep Approach & .34 & .11 & $.31^{* *}$ & 3.00 & .00 \\
\hline 3 & Motivation & & .25 & .07 & $.37^{* *}$ & 3.73 & .00 \\
\hline \multirow[t]{3}{*}{4} & Motivation & Peer Perceived Social Support & .13 & .08 & .17 & 1.63 & .11 \\
\hline & & Deep Approach & & & & & \\
\hline & & & .19 & .07 & $.28^{*}$ & 2.60 & .01 \\
\hline
\end{tabular}

$* \mathrm{p}<.05, * * \mathrm{p}<.01$.

Sobel test $=.2 .04, \mathrm{p}<.05$ (significant)

\section{Discussion}

The aim of this study was to determine if learning approaches mediate the relationship between peer perceived social support and self-regulated learning. Result shows that the impact of peer support on students' ability to process the information was not mediated by learning approach. It seems that students relied on their own ability to process information rather than getting help from their friends. Results from this study also show perfect mediation by deep learning approach. This implies that social support from peers affect students' motivation primarily because of their use of deep approach in learning process. This findings show that peers plays an 
important role in shaping students' attitude for succeeding in universities or colleges. Peers also guide the students by showing better learning approaches as well as help them to understand learning process and motivate them in learning. Based on the findings, the following theoretical and practical applications are suggested in order to be applied specifically among engineering undergraduates.

\section{Reference}

Baron, R. M., \& Kenny, D. A. (1986). The Moderator-Mediator Variable Distinction in Social Psychological Research: Conceptual, Strategic, and Statistical Considerations. Journal of Personality and Social Psychology, 61(6), 1173-1182. http://dx.doi.org/10.1037/0022-3514.51.6.1173

Biggs, J. B. (1987a). Student Approaches to Learning and Studying. Camberwell, Vic.: Australian Council for Educational Research.

Biggs, J. B. (1987b). The Study Process Questionnaire (SPQ): Manual. Hawthorn, Vic.:Australian Council for Educational Research.

Biggs, J. B. (1987c). The Learning Process Questionnaire (LPQ): Manual. Hawthorn, Vic.: Australian Council for Educational Research.

Biggs, J. B., Kember, D., \& Leung, D. Y. P. (2001). The Revised Two Factor Study Process Questionnaire: R-SPQ-2F. British Journal of Educational Psychology, 71, 133-149. http://dx.doi.org/10.1348/0007099 01158433

Carter, E. W., Cushing, L. S., \& Kennedy, C. H. (2000). Peer Support Strategies for Improving All Students' Social Lives and Learning. Paul H. Brookes Publishing Co. Inc.

Perry, N., Phillips, L., \& Hutchinson, L. (2006). Mentoring student teachers to support self-regulated learning. The Elementary School Journal, 106(3), 237-254. http://dx.doi.org/10.1086/501485

Phan Huy, P. (2008). Multiple regression analysis of epistemological beliefs, learning approaches and selfregulated learning. Electronic Journal of Educational Psychological, 6(1), 157-184.

Pintrich, P. R., \& Schunk, D. H. (2002). Motivation in education: Theory, research, and applications. New Jersey: Merrill Prentice-Hall.

Rubel, D. P. (2008). Perceived Classmate, Teacher and Parent Support and self-regulated learning skills during middle school (Unpublished Doctoral Thesis). Fordham University, New York.

Schunk, D. H. (2001). Social cognitive theory and self-regulated learning. In B. J. Zimmerman, \& D. H. Schunk (Eds.), Self-regulated learning and academic achievement: theoretical perspectives (2nd ed., pp. 125-154). Mawah, NJ: Lawrence Erlbaum Assoc. http://dx.doi.org/10.6018/analesps.30.2.167221

Slavin-Williams, R. C., \& Berdnt, T. J. (1990). Friendship and peer relations. In S. S. Feldman, \& G. R. Elliot (Eds.), At the Threshold: The Developing Adolescent (pp. 277-308). Harvard University Press, Cambridge.

Weinstein, C. E., \& Palmer, D. R. (2002a). LASSI: User's manual (2nd ed.). Clearwater, FL: H\&H Publishing Co.

Weinstein, C. E., \& Palmer, D. R. (2002b). Users' manual for those administering the Learning Study Strategies Inventory. Clearwater. FL: Hackworth \& Howland.

Zainal, U. (2009). The Elevation of Higher Learning (Memperkasa Pengajian Tinggi). Penerbit UTM and Institut Terjemahan Negara Malaysia, Kuala Lumpur.

Zimet, G. D., Dahlem, N. W., Zimet, S. G., \& Farley, G. K. (1988). The Multidimensional Scale of Perceived Social Support. Journal of Personality Assessment, 52, 30-41. http://dx.doi.org/10.1207/s15327752 jpa5201_2

Zimet, G. D., Powell, S. S., Farley, G. K., Werkman, S., \& Berkoff, K. A. (1990). Psychometric characteristics of the Multidimensional Scale of Perceived Social Support. Journal of Personality Assessment, 55, 610-617. http://dx.doi.org/10.1207/s15327752jpa5503\&4_17

\section{Copyrights}

Copyright for this article is retained by the author(s), with first publication rights granted to the journal.

This is an open-access article distributed under the terms and conditions of the Creative Commons Attribution license (http://creativecommons.org/licenses/by/3.0/). 